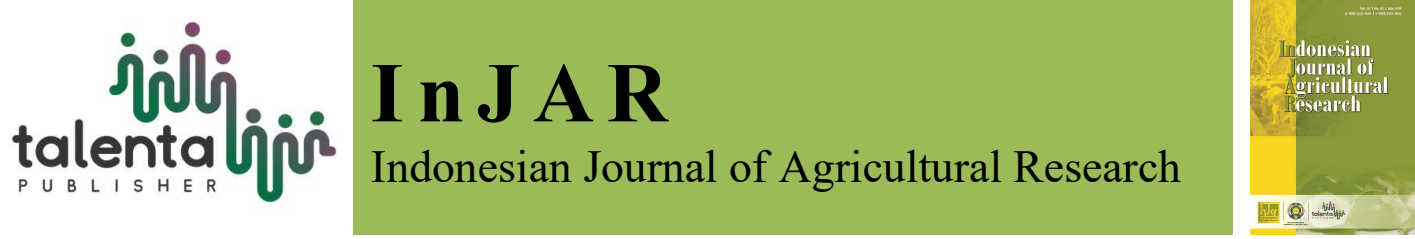

\title{
The Effect of Moringa Leaf Flour Addition in Steamed Sponge Cake Made from a Mixture of Wheat and Banana Flours
}

\author{
Fenny Indah Sari, Hotnida Sinaga*, and Linda Masniary Lubis \\ Department of Food Science and Technology, Faculty of Agriculture, Universitas Sumatera Utara, \\ Indonesia
}

\begin{abstract}
The aim of this study was to determine the suitable Moringa oleifera leaf added for steamed sponge production, which was made from the mixture of wheat and banana flours. This research was conducted. This research was conducted by using completely randomized design with 2 -factors, namely percentage of moringa leaf flour $(\mathrm{K}):(0,0 \%$; $1,0 \% ; 2,0 \%)$ and comparison of mixture wheat flour and banana flour $(\mathrm{P}):(100 \%: 0 \%$; $75 \%: 25 \% ; 50 \%: 50 \% ; 25 \%: 75 \%)$. The results showed that the addition of more moringa leaf flour increased the ash, protein and crude fiber contents in the composite flours. The increment might be related to higher ash, protein and fiber contents in moringa leaf flour than that of in both wheat flour and banana flour. In addition, higher banana flour substitution raised the moisture and ash contents. Meanwhile, the specific volume of cake decreased because banana flour does not have gluten. Based on the protein content and organoleptic values, the addition of $2 \%$ moringa leaf flour and the ratio of wheat flour to banana flour (75\%:25\%) produced the best quality of steamed sponge cake.
\end{abstract}

Keywords: banana flour, moringa leaf flour, steamed sponge cake

Received 24 July 2019 | Revised 28 August 2019| Accepted 11 September 2019

\section{Introduction}

At present in the international market, especially Europe and America Moringa plants are becoming the world's attention because the content is abundant, so the scientists call it a magic tree or "Miracle Tree". Based on research by World Health Organizations WHO the benefits of Moringa leaves are very good, because it contains potassium three times more than bananas, four times more calcium than milk, seven times more vitamin $\mathrm{C}$ than oranges, four times more vitamin A than carrots. and twice the protein of milk. Many studies report that Moringa leaves function as antimicrobial, antibacterial, anti-inflammatory (anti-inflammatory), infectious drugs, Ebstein Barr virus (EBV), herpes simplex virus (HSV-l), HIV/AIDS, intestinal worms, bronchitis, liver disorders, antitumor, cancer, prostate, skin cancer, anemia, diabetes, thyroid,

\footnotetext{
*Corresponding author at: Department of Food Science and Technology, Universitas Sumatera Utara, Jl. Prof A. Sofyan 3, Medan, Indonesia

E-mail address: hotnida.sinaga@uq.net.au
} 
nervous disorders, colic in the digestive tract, rheumatism, headaches, antioxidants, sources of nutrition and tonics.

Besides being consumed fresh, Moringa leaves are also processed into flour form so that the shelf life is longer. Moringa leaf flour many are used as additives for dry or wet foods with the intention of can increase nutritional value like on sponge cake. There are many kinds of sponge cake, for example tart cake which is usually served for weddings and birthdays and which can be served for other events.

In general, sponge cake cooked in two ways are baked in the oven and steamed. The main constituent material in making steamed sponge cakes are wheat flour, eggs, and sugar. Where flour functions to form bread tissue and has a unique protein content that forms a sticky and elastic mass when moistened with water .

Indonesia has very high wheat needs. Data from the Central Statistics Agency (BPS) recorded that Indonesia's total wheat imports in 2016 reached 10.53 million tons, a $42 \%$ increase from the previous year of only 7.4 million tons. So there needs to be an alternative done for the substitution of flour with other flour which has the same function and content. Therefore, the use of bananas that are not tasty consumed in ripe conditions is processed into flour to be used as a variety of innovative products as a new economic strategy to increase the use of bananas, as well as replacing flour in making cakes. In addition, banana flour is also developed as a food that can prevent disease (nutritional) with a low glycemic index.

The purpose of this study was to determine the effect of adding moringa leaf flour to the nutritional content of steamed cake using banana flour.

\section{Material and Methods}

The materials used in this study were white kepok banana, moringa leaf, wheat flour, eggs, margarine, sugar, cake emulsifier, baking powder, vanilla, liquid milk. Reagensia used in this study is concentrated $\mathrm{H} 2 \mathrm{SO} 4, \mathrm{~K} 2 \mathrm{SO} 4, \mathrm{CuSO} 4$, hexane, $\mathrm{NaOH}, \mathrm{CuSO} 2$, aquades, and ethanol $90 \%$.

\subsection{Producing Moringa Flour}

Raw materials of green moringa leaves are selected, washed using clean water and traced from leaf stalks and then drained. After that the leaves are spread on a baking sheet and adjust the thickness with the aim of being able to dry evenly. Then dried in the oven at $45 \mathrm{oC}$ for about 15 hours. After the leaves are dried, refinement is done by using a blender until smooth and done using a 80 mesh size sieve and stored in airtight plastic, it will produce Moringa leaf flour. 


\subsection{Producing Banana Flour}

The raw material for the old Kepok banana which is green, with the characteristics of bananas at harvest age is approximately 80 days after flowering with full aging. Sorting is done, then stripping is done to separate the skin from the fruit flesh. After that the fruit is sliced with a thickness of $0.5-1 \mathrm{~cm}$, then immersed in a metabisulfite solution $(2 \%)$ in $1000 \mathrm{ml}$ for 10 minutes. Then do the sun drying for 8 hours (K.A 8-10\%). After that, milling and sifting are carried out 60 mesh so that banana flour will be produced.

\subsection{Producing Steamed Sponge}

The First is weighed wheat flour and banana flour with a ratio of $100 \%: 0 \% ; 75 \%: 25 \%$; 50\%:50\%; and 25\%:75\% of $200 \mathrm{~g}$ weight of flour, then each supplementary supplementary ingredient is added, namely margarine 25\% (50 g), 80\% sugar (160 g), egg 50\% (100 g), 5\% emulsifier cake (10 g), vanilla 1\% (2 g), baking powder 1.5\% (3 g) and liquid milk 50\% (100 g) and then the mixture is mixed for 7 minutes at medium speed.

Both ingredients that have been mixed, added with $0 \%(0 \mathrm{~g}), 1 \%(2 \mathrm{~g})$ and 2\% (4 g) Moringa leaf flour while stirring until evenly distributed (homogeneous). The three doughs are poured into an available cup weighing $20 \mathrm{~g}$ and steamed in a steaming pot using a temperature of $90 \mathrm{oC}$ on the stove over medium heat for 15 minutes then a steamed sponge will be analyzed.

\section{Data Analysis}

This research was conducted using a Completely Randomized Design (CRD) consisting of two factors, namely factor I: addition of Moringa flour (\%) consisting of 3 levels (K), namely K1 = $0 \% ; \mathrm{K} 2=1 \% ; \mathrm{K} 3=2 \%$; and factor II: comparison of wheat flour: kepok white banana flour which consists of 4 levels $(\mathrm{P})$, namely $\mathrm{P} 1=0 \%: 100 \%$; $\mathrm{P} 2=75 \%: 25 \%$; $\mathrm{P} 3=50 \%: 50 \%$; and $\mathrm{P} 4$ $=25 \%: 75 \%$. The number of combinations of treatment or Treatment Combination $(\mathrm{Tc})$ is 12 . Each treatment is made in 3 replications, with total of 36 samples. The parameters analyzed were: proximate composition consists of moisture content by gravimetric method, ash content by gravimetric method. protein content (Kjeldahl method), crude fiber content by using acid hydrolysis method and specific volume of cake by displacement test method. Sensory testing by organoleptic test (preference test) 1-5 scale includes flavor.

\section{Results and Discussions}

\subsection{Moisture Content}

From the list of variants it can be seen that the effect of the comparison of wheat flour and banana flour has a significant effect $(\mathrm{P}<0.05)$ on the moisture content of steamed sponge. LSR 
test results from the effect of the comparison of wheat flour and banana flour on the water content can be seen in Table 1.

Table 1. LSR Test the Effect of Comparison of Wheat Flour and Banana Flour Affect the Water Content of Steamed Sponge

\begin{tabular}{ccccc}
\hline Range & $\begin{array}{c}\text { LSR } \\
\mathbf{0 . 0 5}\end{array}$ & Treatment & Average & $\begin{array}{c}\text { Notation } \\
\mathbf{0 . 0 5}\end{array}$ \\
\hline- & - & $\mathrm{P}_{1}=100 \%: 0 \%$ & 22.18 & $\mathrm{~b}$ \\
2 & 1.2216 & $\mathrm{P}_{2}=75 \%: 25 \%$ & 22.32 & $\mathrm{~b}$ \\
3 & 1.2832 & $\mathrm{P}_{3}=50 \%: 50 \%$ & 22.83 & $\mathrm{ab}$ \\
4 & 1.3225 & $\mathrm{P}_{4}=25 \%: 75 \%$ & 24.04 & $\mathrm{a}$ \\
\hline
\end{tabular}

From Table 1 it can be seen that the treatment of $\mathrm{P} 1$ is not significantly different from treatment of $\mathrm{P} 2$ and $\mathrm{P} 3$, it is significantly different from P4. P2 treatment was not significantly different from P3 treatment, significantly different from P4. P3 treatment was not significantly different from P4. The treatment that has the highest water content is treatment P4 (25\%:75\%) at $24.04 \%$ and lowest water content in treatment P1 (100\%:0\%) at 22.18\%. The higher the addition of banana flour that is used, the water content of steamed sponge will increase. This is due to the high content of crude fiber found in bananas which is around $2.24 \%$ while in wheat flour it is less, which is equal to $1.00 \%$, so the higher the banana flour in the product will cause an increase in water content.

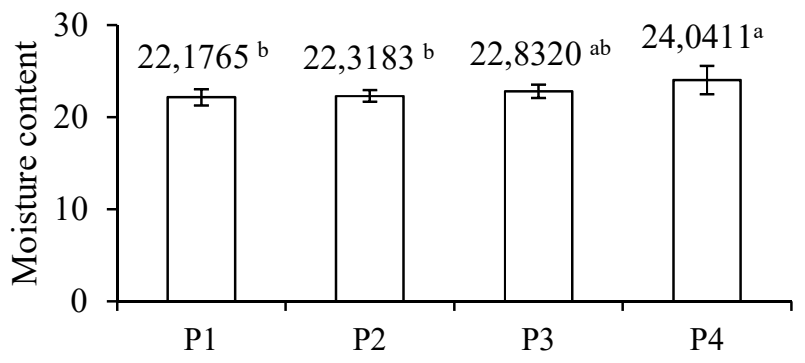

\section{Comparison of wheat flour and banana flour}

Figure 1. Relation of Comparison of Wheat Flour and Banana Flour to Moisture Content of Steamed Sponge

\subsection{Ash Content}

From the list of variants it can be seen that the effect of adding moringa leaf flour has a significant effect $(\mathrm{P}<0.01)$ on the ash content of steamed sponge. LSR test results from the effect of adding moringa leaf flour to ash content can be seen in Table 2 .

Table 2. LSR Test Effect of Addition of Moringa Leaf Flour of the Ash Content of Steamed Sponge

\begin{tabular}{ccccc}
\hline Range & $\begin{array}{c}\text { LSR } \\
\mathbf{0 . 0 1}\end{array}$ & Treatment & Average & $\begin{array}{c}\text { Notation } \\
\mathbf{0 . 0 1}\end{array}$ \\
\hline- & - & $\mathrm{K}_{1}=0 \%$ & 1.1529 & $\mathrm{~B}$ \\
2 & 0.1074 & $\mathrm{~K}_{2}=1 \%$ & 1.3087 & $\mathrm{~A}$ \\
3 & 0.1121 & $\mathrm{~K}_{3}=2 \%$ & 1.3592 & $\mathrm{~A}$ \\
\hline
\end{tabular}


From Table 2 it can be seen that the treatment of $\mathrm{K} 1$ treatment is very significantly different from the $\mathrm{K} 2$ and $\mathrm{K} 3$ treatments. K2 treatment was not significantly different from the K3 treatment. The treatment with the highest ash content was $\mathrm{K} 3(2 \%)$ treatment at $1.36 \%$ and the lowest ash content was treatment K1 $(0 \%)$ at $1.1529 \%$. The higher the addition of moringa leaf flour, the higher the content of steamed sponge ash produced, this is due to the high ash content of Moringa leaf flour which is about $11.50 \%$. Moringa leaf is one part of a plant that is rich in nutrients, including iron. moringa leaves contain higher iron than other vegetables, which is $17.20 \mathrm{mg} / 100 \mathrm{~g}[1]$.

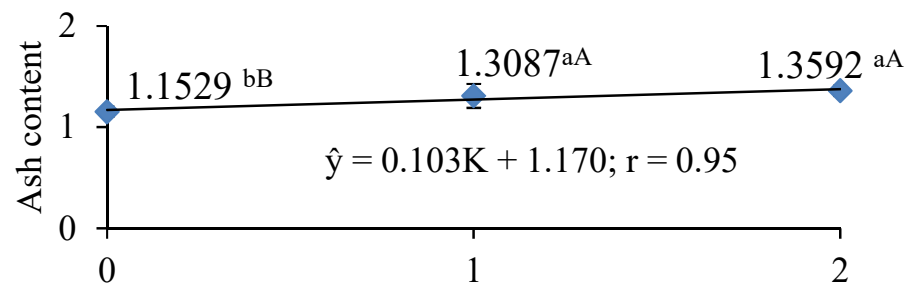

Moringa leaf flour concentration

Figure 2. Relation of Moringa Leaf Flour Concentration to Ash Content of Steamed Sponge From the list of variants it can be seen that the effect of the comparison of wheat flour and banana flour has a significant effect $(\mathrm{P}<0.05)$ on the ash content of steamed sponge. LSR test results from the effect of the comparison of wheat flour and banana flour on ash content can be seen in Table 3.

Table 3. LSR Test the Effect of Comparison of Wheat Flour and Banana Flour Affect the Ash Content of Steamed Sponge

\begin{tabular}{ccccc}
\hline Range & $\begin{array}{c}\text { LSR } \\
\mathbf{0 . 0 5}\end{array}$ & Treatment & Average & $\begin{array}{c}\text { Notation } \\
\mathbf{0 . 0 5}\end{array}$ \\
\hline- & - & $\mathrm{P}_{1}=100 \%: 0 \%$ & 1.21 & $\mathrm{~b}$ \\
2 & 0.0916 & $\mathrm{P}_{2}=75 \%: 25 \%$ & 1.27 & $\mathrm{ab}$ \\
3 & 0.0962 & $\mathrm{P}_{3}=50 \%: 50 \%$ & 1.27 & $\mathrm{ab}$ \\
4 & 0.0991 & $\mathrm{P}_{4}=25 \%: 75 \%$ & 1.34 & $\mathrm{a}$ \\
\hline
\end{tabular}

From Table 2 it can be seen that the treatment of $\mathrm{P} 1$ is not significantly different from treatment of $\mathrm{P} 2$ and $\mathrm{P} 3$, it is significantly different from P4. P2 treatment was not significantly different from treatment P3 and P4. P3 treatment was not significantly different from the P4 treatment. The treatment with the highest ash content was treatment P4 (25\%:75\%) at 1.34\% and the lowest ash content was treatment P1 (100\%:0\%) at 1.21\%. The more addition of banana flour, the higher the ash content. Bananas are minerals that are rich in potassium, magnesium, phosphorus, calcium, and iron. When compared with other types of plant foods, banana minerals, especially iron, almost all (100\%) can be absorbed by the body [2] 


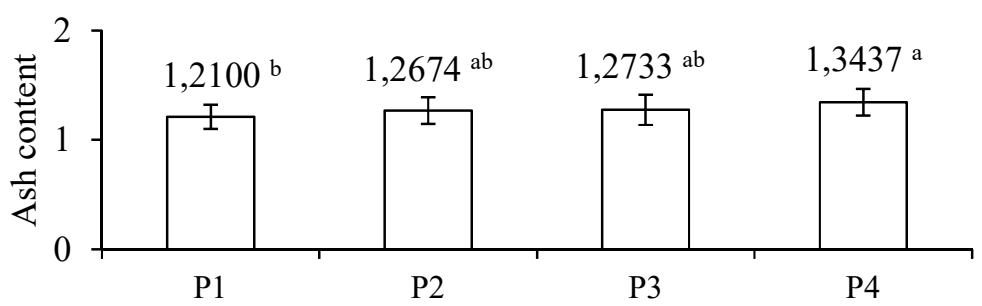

Comparison of wheat flour and banana flour

Figure 3. Relation of Comparison of Wheat Flour and Banana Flour to Ash Content of Steamed Sponge

\subsection{Protein Content}

From the list of variants it can be seen that the effect of adding moringa leaf flour has a significant effect $(\mathrm{P}<0.01)$ on the protein content of steamed sponge. The LSR test results of the effect of adding moringa leaf flour to protein content can be seen in Table 4.

Table 4. LSR Test Effect of Addition of Moringa Leaf Flour the Protein Content of Steamed Sponge

\begin{tabular}{|c|c|c|c|c|}
\hline Range & $\begin{array}{l}\text { LSR } \\
0.01\end{array}$ & Treatment & Average & $\begin{array}{c}\text { Notation } \\
0.01\end{array}$ \\
\hline- & - & $\mathrm{K}_{1}=0 \%$ & 2.6245 & B \\
\hline 2 & 0.2088 & $\mathrm{~K}_{2}=1 \%$ & 2.7362 & $\mathrm{AB}$ \\
\hline 3 & 0.2178 & $\mathrm{~K}_{3}=2 \%$ & 2.9496 & A \\
\hline
\end{tabular}

From Table 4 it can be seen that $\mathrm{K} 1$ treatment was not significantly different from the K2 treatment, and it was very significantly different from the $\mathrm{K} 3$ treatment. The $\mathrm{K} 2$ treatment was significantly different from the K3 treatment. The treatment with the highest protein content was treatment of $\mathrm{K} 3(2 \%)$ at $2.95 \%$ and the lowest protein content in the treatment of $\mathrm{K} 1(0 \%)$ at $2.62 \%$. The more addition of moringa leaf flour, the higher the protein content. This is because moringa leaf flour has a fairly high protein content of $19.20 \%$. Moringa leaf flour contains 18 amino acids consisting of all (eight) essential amino acids and 10 nonessential amino acids). Moringa leaves are a source of essential amino acids such as methionine, cystine, tryptophan, and lysine [3].

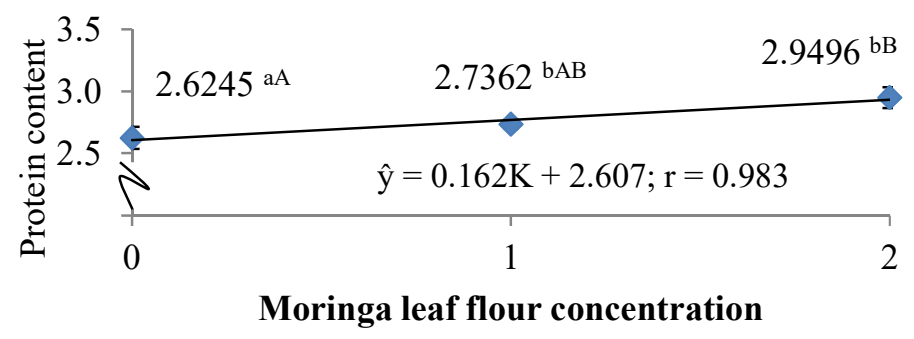

Figure 4. Relation of Moringa Leaf Flour Concentration to Protein Content of Steamed Sponge 


\subsection{Crude Fiber Content}

From the list of variants it can be seen that the effect of adding moringa leaf flour has a significant effect $(\mathrm{P}<0.01)$ on the crude fiber content of steamed sponge. The LSR test results of the effect of adding moringa leaf flour to crude fiber content can be seen in Table 5 .

Table 5. LSR Test Effect of Addition of Moringa Leaf Flour on the Crude Fiber Content of

\begin{tabular}{ccccc}
\hline Range & LSR & Steamed Sponge & Notation \\
& $\mathbf{0 . 0 1}$ & Treatment & Average & .01 \\
\hline- & - & $\mathrm{K}_{1}=0 \%$ & 1.8087 & $\mathrm{~B}$ \\
2 & 0.1658 & $\mathrm{~K}_{2}=1 \%$ & 1.9017 & $\mathrm{~A}$ \\
3 & 0.1730 & $\mathrm{~K}_{3}=2 \%$ & 2.0840 & \\
\hline
\end{tabular}

From Table 5 it can be seen that the $\mathrm{K} 1$ treatment gives a significantly different effect from the K2 treatment, very significantly different from the K3 treatment. K2 treatment had a very significant effect on the $\mathrm{K} 3$ treatment. The treatment with the highest crude fiber content was treatment of $\mathrm{K} 3(2 \%)$ at $2.08 \%$ and the lowest crude seart content at treatment $\mathrm{K} 1(0 \%)$ at $1.81 \%$. The more addition of moringa leaf flour, the crude fiber content will increase. This is due to the crude fiber content in high moringa leaves, which is $13.69 \%$. Kelor has leaves that are widely used because fresh moringa leaves contain $6.9 \mathrm{mg}$ of fiber while dried moringa leaves per 100 grams contain 19.2 grams of fiber [4].

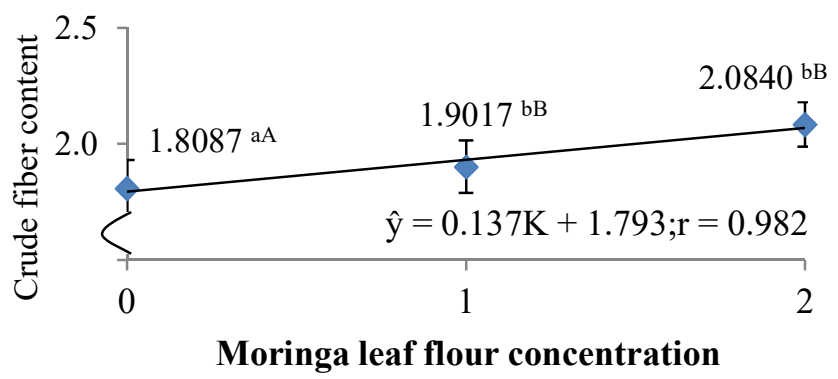

Figure 5. Relation of Moringa Leaf Flour Concentration to Crude Fiber Content of Steamed Sponge

\subsection{Specific Volume of Cake}

From the list of variants it can be seen that the effect of the comparison of wheat flour and banana flour has a significant effect $(\mathrm{P}<0.01)$ on the specific volume of steamed sponge. LSR test results from the effect of the comparison of wheat flour and banana flour on specific volume of cake can be seen in Table 6 . 
Table 6. LSR Test the Effect of Comparison of Wheat Flour and Banana Flour Affect the Specific Volume of Steamed Sponge

\begin{tabular}{ccccc}
\hline Range & $\begin{array}{c}\text { LSR } \\
\mathbf{0 . 0 1}\end{array}$ & Treatment & Average & $\begin{array}{c}\text { Notation } \\
\mathbf{0 . 0 1}\end{array}$ \\
\hline- & - & $\mathrm{P}_{1}=100 \%: 0 \%$ & 2.9508 & $\mathrm{~A}$ \\
2 & 0.1623 & $\mathrm{P}_{2}=75 \%: 25 \%$ & 2.6744 & $\mathrm{~B}$ \\
3 & 0.1693 & $\mathrm{P}_{3}=50 \%: 50 \%$ & 2.6652 & $\mathrm{~B}$ \\
4 & 0.1739 & $\mathrm{P}_{4}=25 \%: 75 \%$ & 2.6532 & $\mathrm{~B}$ \\
\hline
\end{tabular}

From Table 6 it can be seen that the treatment of P1 is very significantly different from treatment of P2, P3 and P4. P2 treatment was not significantly different from treatment P3 and P4. P3 treatment was not significantly different from P4. The treatment with the highest specific volume of cake was treatment P1 (100\%: $0 \%)$ at $2.95 \%$ and the lowest specific cake volume in treatment P4 $(75 \%: 25 \%)$ at $2.65 \%$. The use of wheat flour has an effect on the specific volume of steamed sponge, the more wheat flour is used the more it increases while the more banana flour used by the specific volume of steamed sponge cake decreases. This is because wheat flour contains gluten compounds while banana flour does not contain gluten, therefore it needs to be mixed with other flour so that it can crisp and expand [5].

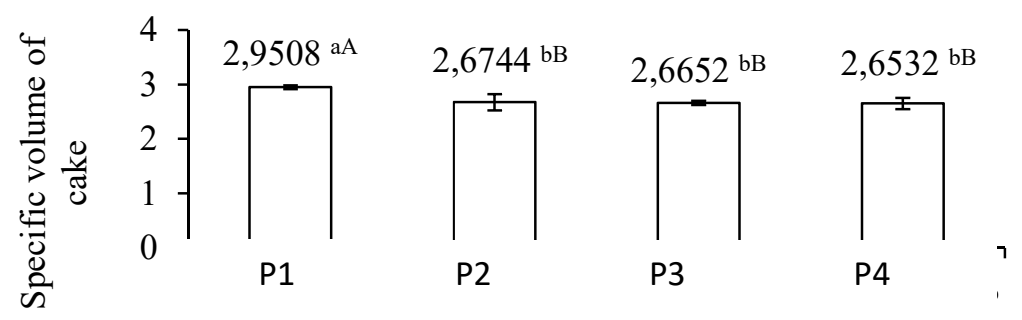

Comparison of wheat flour and banana flour

Figure 6. Relation of Comparison of Wheat Flour and Banana Flour to Specific Cake of Steamed Sponge

\subsection{Hedonic Value of Taste}

From the list of variants it can be seen that the effect of adding moringa leaf flour has a significant effect $(\mathrm{P}<0.01)$ on the hedonic value taste of steamed sponge. The LSR test results of the effect of adding moringa leaf flour to hedonic value of taste can be seen in Table 7 .

Table 7. LSR Test Effect of Addition of Moringa Leaf Flour on the Hedonic Value Taste of Steamed Sponge

\begin{tabular}{|c|c|c|c|c|}
\hline Range & $\begin{array}{l}\text { LSR } \\
0.01\end{array}$ & Treatment & Average & $\begin{array}{c}\text { Notation } \\
\mathbf{0 . 0 1} \\
\end{array}$ \\
\hline - & - & $\mathrm{K}_{1}=0 \%$ & 3.88 & $\mathrm{~A}$ \\
\hline 2 & 0.1392 & $\mathrm{~K}_{2}=1 \%$ & 3.74 & A \\
\hline 3 & 0.1452 & $\mathrm{~K}_{3}=2 \%$ & 3.19 & B \\
\hline
\end{tabular}


From Table 7 it can be seen that $\mathrm{K} 1$ treatment has a significantly different effect from K2 treatment, very significantly different from $\mathrm{K} 3$ treatment. The $\mathrm{K} 2$ treatment had a very significant effect on the $\mathrm{K} 3$ treatment. The treatment that has the highest hedonic taste value is $\mathrm{K} 1(0 \%)$ and the treatment that has the lowest hedonic taste value is $\mathrm{K} 3(2 \%)$. The addition of moringa leaf flour to steamed sponge products will provide a bitter taste wherein there are tannin compounds that can cause dryness and wrinkles in the mouth [6].

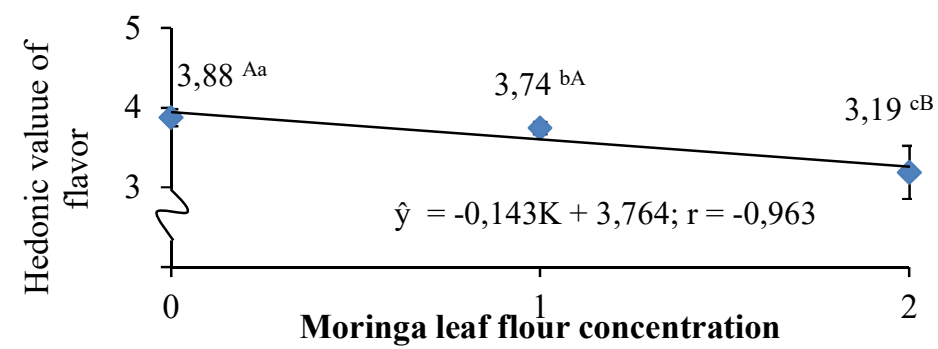

Figure 7. Relation of Moringa Leaf Flour Concentration to Hedonic Value of Flavor to Steamed Sponge

From the list of variants it can be seen that the effect of the comparison of wheat flour and banana flour has a significant effect $(\mathrm{P}<0.01)$ on the hedonic value taste of steamed sponge. LSR test results from the effect of the comparison of wheat flour and banana flour on hedonic value taste of cake can be seen in Table 8 .

Table 8. LSR Test the Effect of Comparison of Wheat Flour and Banana Flour Affect the Hedonic Value Taste of Steamed Sponge

\begin{tabular}{ccccc}
\hline Range & $\begin{array}{c}\text { LSR } \\
\mathbf{0 . 0 1}\end{array}$ & Treatment & Average & $\begin{array}{c}\text { Notation } \\
\mathbf{0 . 0 1}\end{array}$ \\
\hline- & - & $\mathrm{P}_{1}=100 \%: 0 \%$ & 3.4278 & $\mathrm{~B}$ \\
2 & 0.1607 & $\mathrm{P}_{2}=75 \%: 25 \%$ & 3.6167 & $\mathrm{~A}$ \\
3 & 0.1677 & $\mathrm{P}_{3}=50 \%: 50 \%$ & 3.6667 & $\mathrm{~A}$ \\
4 & 0.1723 & $\mathrm{P}_{4}=25 \%: 75 \%$ & 3.6944 & $\mathrm{~A}$ \\
\hline
\end{tabular}

From Table 8 it can be seen that the treatment of $\mathrm{P} 1$ is very significantly different from treatment of P2, P3 and P4. P2 treatment was not significantly different from treatment P3 and P4. P3 treatment was not significantly different from P4. The treatment that has the highest hedonic taste value is P4 (25\%:75\%)and the treatment that has the lowest hedonic taste value is $\mathrm{P} 1(100 \%: 0 \%$. This is because the higher the percentage of banana flour that is used, the more sweet the taste of steamed sponge, where the sweet taste comes from the white kepok banana flour that is used contains high levels of starch. White kepok banana has a high content of starch compared to other types of bananas in the amount of $64.69-67.31 \%$ which can produce a banana flour yield of $15.4-18.8 \%$ of their flesh [7]. 


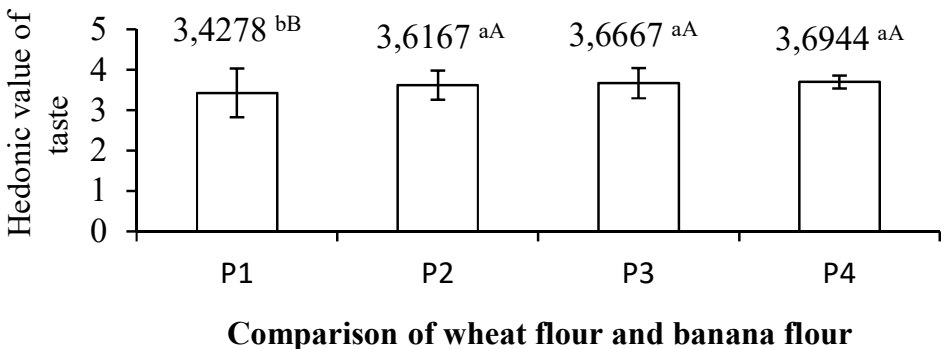

Figure 8. Relation of Comparison of Wheat Flour and Banana Flour to Hedonic Value Taste of Steamed Sponge

From the list of variants it can be seen that the interaction has a significant effect $(\mathrm{P}<0.01)$ on the hedonic value taste of steamed sponge. LSR test results from the interaction of on hedonic value taste of cake can be seen in Table 9 .

Table 9. LSR Test the Interaction on Value Taste of Steamed Sponge

\begin{tabular}{ccccc}
\hline Range & $\begin{array}{c}\text { LSR } \\
\mathbf{0 , 0 5}\end{array}$ & Treatment & Avenger & $\begin{array}{c}\text { Notasi } \\
\mathbf{0 , 0 1}\end{array}$ \\
\hline- & - & $\mathrm{K}_{1} \mathrm{P}_{1}$ & 3.8167 & $\mathrm{AB}$ \\
2 & 0.2054 & $\mathrm{~K}_{1} \mathrm{P}_{2}$ & 3.8000 & $\mathrm{AB}$ \\
3 & 0.2158 & $\mathrm{~K}_{1} \mathrm{P}_{3}$ & 4.0333 & $\mathrm{~A}$ \\
4 & 0.2224 & $\mathrm{~K}_{1} \mathrm{P}_{4}$ & 3.8500 & $\mathrm{AB}$ \\
5 & 0.2271 & $\mathrm{~K}_{2} \mathrm{P}_{1}$ & 3.7333 & $\mathrm{AB}$ \\
6 & 0.2306 & $\mathrm{~K}_{2} \mathrm{P}_{2}$ & 3.8500 & $\mathrm{AB}$ \\
7 & 0.2333 & $\mathrm{~K}_{2} \mathrm{P}_{3}$ & 3.6833 & $\mathrm{~B}$ \\
8 & 0.2354 & $\mathrm{~K}_{2} \mathrm{P}_{4}$ & 3.7000 & $\mathrm{~B}$ \\
9 & 0.2372 & $\mathrm{~K}_{3} \mathrm{P}_{1}$ & 2.7333 & $\mathrm{E}$ \\
10 & 0.2386 & $\mathrm{~K}_{3} \mathrm{P}_{2}$ & 3.2000 & $\mathrm{D}$ \\
11 & 0.2397 & $\mathrm{~K}_{3} \mathrm{P}_{3}$ & 3.2833 & $\mathrm{CD}$ \\
12 & 0.2407 & $\mathrm{~K}_{3} \mathrm{P}_{4}$ & 3.5333 & $\mathrm{BC}$ \\
\hline
\end{tabular}

From Table 8 it can be seen that the combination of the addition of Moringa leaf flour and the ratio of flour to banana flour in steamed sponges have a very significant effect on the value of hedonic flavor. The treatment of K1P4 at 0\% Moringa leaf flour and the ratio of wheat flour to banana flour (25\%:75\%) had the highest hedonic taste value of all treatments was $4.03 \%$, while treatment with the lowest hedonic value was K3P1 in 2\% leaf flour Moringa and the ratio of wheat flour to banana flour $(100 \%: 0 \%)$ are at $2.73 \%$. This is because the bitter taste produced by Moringa leaf flour is acceptable to consumers from the sweet taste produced by banana flour. 


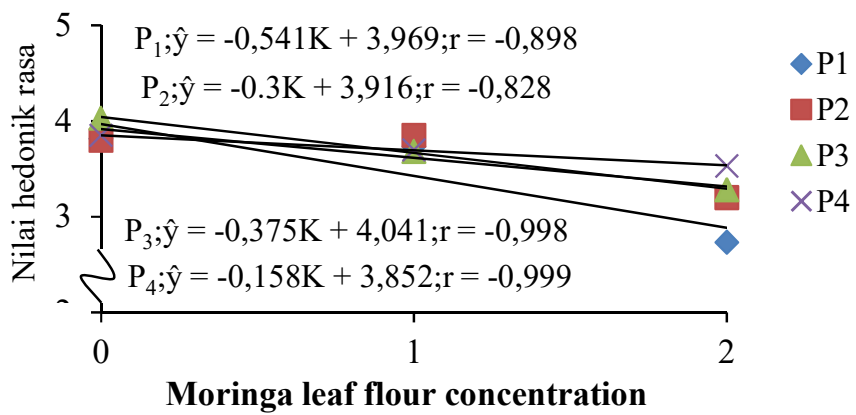

Figure 10. Relation the Interaction Effect on the Hedonic Value Taste of Steamed Sponge

\section{Conclusions}

From the results of the study the effect of adding Moringa leaf flour in the manufacture of steamed dumplings using white flour and Kepok banana flour to parmeter observed can be concluded as follows:

1. Addition of leaf flour has a very significant different effect on ash content, protein content, carbohydrate content, crude fiber content, hedonic color value, hedonic flavor value, hedonic texture value and gives a significantly different effect on hedonic value of general acceptance.

2. Comparison of wheat flour with banana flour gives a very significant different effect on carbohydrate content, specific volume of cake, hedonic color value, hedonic flavor value, hedonic texture value, general acceptance hedonic value and gives a significant different effect on water content, ash content, and hedonic value of aroma.

3. The interaction between the addition of Moringa leaf flour and the ratio of wheat flour to banana flour gave a very significant different effect on carbohydrate content and hedonic value of flavor while the hedonic value of color and hedonic value of general acceptance gave a significantly different effect. However, it has no significant effect on water content, ash content, fat content, protein content, crude fiber content, specific volume of cake, hedonic aroma value and hedonic texture value.

4. The best moringa steamed sponge cake is the addition of $2 \%$ Moringa leaf flour and the ratio of wheat flour to banana flour (75\%:25\%). The selection of the best treatment is done based on the De Garmo effectiveness index test.

\section{REFERENCES}

[1] W. C. Yameogo, D. M. Bengaly, and S. A. Traore, "Determination of chemical composition and nutritional values of moringa oleifera leaves," Pakistan Journal of Nutrition, vol. 10, no. 3, pp. 264-268, 2011. 
[2] B. Mandieta-Araica, E. Sporndly, N. Reyes-sanchez, Salmeron-Miranda, and M. F. Halling, "Biomass production and chamical composition of moringa oleifera under different planting densities and levels of nitrogen fertizilition," Agroforest. Sist, vol. 8, no. 7, pp. 8192, 2013.

[3] A. C. Mehta, U. B. Prakash, R. Garland, E. Haponik, L. Moses, W. Schaffner, and G. Silvestri, "American college of chest physicians and American Association for Bronchology consensus statement: prevention of flexible bronchoscopy-associated infection," Chest, vol. 128, no. 3, pp. 1742-1755, 2005.

[4] G. P. Singh, R. G. Sudeep, and S. Kumar, "Anti-inflammatory evaluation of leaf extract of moringa oleifera," Journal of Pharmaeutical and Scientific Innovation, vol. 1, no. 1, pp. 22-24, 2012.

[5] V. S. Srikanth, S. Mangala, and G. Subrahmanyam, "Improvement of protein energy malnutrition by nutritional intervention with moringa oleifera among anganwadi children in rural area in Bangalore, India," International Journal of Scientific Study, vol. 2, no. 1, pp. 32-35, 2014.

[6] F. Umi, "Pengaruh campuran bekatul pada produk cookies terhadap sifat fisik, organoleptik, dan kadar serat," Jurnal Nutrisia, vol. 15, no. 1, pp. 48-52, 2012.

[7] Ismarani, "Potensi senyawa tanin dalam menunjang produksi ramah lingkungan," Jurnal Agribisnis dan Pengembangan Wilayah, vol. 3, no. 2, pp. 46-55, 2012. 